\title{
A comparison between the $\beta$-globin gene clusters of domestic sheep (Ovis aries) and Sardinian mouflon (Ovis gmelini musimon)
}

\author{
A Rando ${ }^{1}$, P Di Gregorio ${ }^{2}$, M Capuano ${ }^{1}$, C Senese ${ }^{1}$, \\ L Manca $^{2}$, S Naitana ${ }^{3}$, B Masala ${ }^{2}$ \\ 1 Dipartimento di Scienze delle Produzioni Animali, \\ Università degli Studi della Basilicata, Via N Sauro 85, 85100 Potenza; \\ ${ }^{2}$ Istituto di Fisiologia Generale e Chimica Biologica, \\ Università degli Studi di Sassari, Via Muroni 25; \\ ${ }^{3}$ Istituto di Fisiologia degli Animali Domestici, Università degli Studi di Sassari, \\ Via Vienna 2, 07100 Sassari, Italy
}

(Received 15 March 1995; accepted 15 February 1996)

Summary - The organization of the $\beta$-globin gene cluster of wild Sardinian mouflons with different haemoglobin phenotypes has been analyzed by means of Southern blot with probes specific for $\varepsilon^{I V}$ - and $\beta^{F}$ - globin genes. With three endonucleases (Bam HI, Eco $\mathrm{RI}$, and Hind III), Sardinian mouflons with $\mathrm{Hb} \mathrm{B}, \mathrm{Hb} \mathrm{BM}$ and $\mathrm{Hb} \mathrm{M}$ show identical restriction patterns to sheep with $\mathrm{Hb} \mathrm{A}, \mathrm{Hb} \mathrm{AB}$, and $\mathrm{Hb} \mathrm{B}$, respectively. Therefore, in Sardinian mouflons as in domestic sheep, the $\beta$-globin gene cluster shows two haplotypes characterized by the triplication or duplication of an ancestral four gene set $(\varepsilon-\varepsilon-\psi \beta-\beta)$.

domestic sheep / Sardinian mouflon / haemoglobin / $\beta$-globin cluster

Résumé - Comparaison du groupe de gènes de la globine- $\beta$ du mouton domestique (Ovis aries) et du mouflon de Sardaigne (Ovis gmelini musimon). L'organisation du groupe de gènes de la globine- $\beta$ chez des mouflons de Sardaigne montrant divers phénotypes d'hémoglobine a été analysée par buvardage de Southern avec des sondes spécifiques pour les gènes $\varepsilon^{\mathrm{IV}}$ et $\beta^{\mathrm{F}}$. Avec trois endonucléases (Bam HI, Eco RI et Hind III), les mouflons caractérisés par les phénotypes d'hémoglobine $B, B M$ et $M$ montrent des patrons de restriction identiques aux moutons ayant les phénotypes d'hémoglobine $A, A B$ et $B$ respectivement. Par conséquent, le groupe de gènes de la globine- $\beta$ manifeste dans ces deux espèces deux haplotypes caractérisés par la duplication ou le triplement d'un ensemble de quatre gènes ancestraux : $\varepsilon-\varepsilon-\psi \beta-\beta$.

mouton / mouflon de Sardaigne / hémoglobine / globine- $\beta$ 


\section{INTRODUCTION}

The domestic sheep (Ovis aries) $\beta$-globin gene cluster shows two common haplotypes: the $\mathrm{A}$ haplotype bearing the adult $H B B^{A}$ allele and the $\mathrm{B}$ haplotype bearing the adult $H B B^{B}$ allele (Garner and Lingrel, 1988, 1989). The A haplotype is similar to the goat (Capra hircus) $\beta$-globin gene cluster (Townes et al, 1984) and shows the triplication $\left(5^{\prime} \varepsilon^{\mathrm{I}}-\varepsilon^{\mathrm{II}}-\psi \beta^{\mathrm{I}}-\beta^{\mathrm{C}}-\varepsilon^{\mathrm{III}}-\varepsilon^{\mathrm{IV}}-\psi \beta^{\mathrm{II}}-\beta^{\mathrm{A}}-\varepsilon^{\mathrm{V}}-\varepsilon^{\mathrm{VI}}-\psi \beta^{\mathrm{III}}-\beta^{\mathrm{F}} 3^{\prime}\right)$ of an ancestral four gene set $(\varepsilon-\varepsilon-\psi \beta-\beta)$ characterized by two embryonic genes $(\varepsilon)$, one pseudogene $(\psi \beta)$, and one gene $(\beta)$ whose expression varies as a function of ontogenic development and physiological conditions. In fact, $\beta^{\mathrm{C}}, \beta^{\mathrm{A}}$, and $\beta^{\mathrm{F}}$ genes are expressed during juvenile, adult, and fetal life, respectively (Huisman et al, 1969). The $\beta^{\mathrm{C}}$ and $\beta^{\mathrm{A}}$ switch is reversible under particular physiological or experimental conditions (anaemia, hypoxia or under administration of erythropoietin) (Huisman et al, 1967; Boyer et al, 1968). The B haplotype, lacking the whole juvenile fourgene set, is duplicated $\left(5^{\prime} \varepsilon^{\mathrm{I}}-\varepsilon^{\mathrm{II}}-\psi \beta^{\mathrm{I}}-\beta^{\mathrm{B}}-\varepsilon^{\mathrm{III}}-\varepsilon^{\mathrm{IV}}-\psi \beta^{\mathrm{II}}-\beta^{\mathrm{F}} 3^{\prime}\right)$. Therefore, sheep homozygous for the $H B B^{B}$ allele do not exhibit the property of $\beta^{\mathrm{B}} \rightarrow \beta^{\mathrm{C}}$ switching as they do not possess the $\beta^{\mathrm{C}}$ gene. Since domestic sheep $\beta^{\mathrm{A}}$ and $\beta^{\mathrm{B}}$ allelic chains differ by at least seven scattered amino-acid residues and no intermediate haplotype has been found, it has been proposed that this polymorphism is the product of genetic isolation followed by admixture (Boyer et al, 1966). Manwell and Baker (1976) suggest that man has played a role in generating haemoglobin polymorphisms in domesticating sheep by hybridizing individuals that would otherwise be geographically isolated. Southern blot analysis, using $\beta$-like globin genes as probes and several endonucleases, strongly supports the polyphyletic origin of the domestic sheep. In fact, by means of this technique, A and B haplotypes can be easily distinguished since they differ in both number and length of restriction fragments and show no intermediates (Di Gregorio et al, 1987; Rando et al, 1989).

Some authors (Bunch et al, 1976; Bunch and Nadler, 1980; Bunch and Nguyen, 1982; Ryder, 1984; Di Gregorio et al, 1987) consider the mouflon as one of the ancestors of the present day domestic sheep, whereas others (Poplin, 1979; Vigne, 1983) claim that it originated by feralization of the first domesticated sheep in the Corsico-Sardinian islands (Neolithic).

In wild mouflons (Ovis gmelini musimon) captured in Sardinia, two alleles at the adult $\beta$-globin locus have been observed: $H B B^{B}$ and $H B B^{M}$, with frequencies of 0.94 and 0.06 respectively. Both adult $\beta$-globin variants in this species are electrophoretically different from those observed in sheep (Naitana et al, 1990). No homozygous individuals for the $H B B^{M}$ allele had been found (Naitana et al, $1990)$. In this paper, with the availability of a mouflon homozygous for the $H B B^{M}$ allele, we compared the organization of the $\beta$-globin clusters of wild Sardinian mouflons and domestic sheep with different $\mathrm{Hb}$ phenotypes by means of Southern blot analysis.

\section{MATERIALS AND METHODS}

Haemoglobin phenotypes of sheep and wild Sardinian mouflons were determined by means of isoelectric focusing in the $\mathrm{pH}$ range 6.7-7.7 and by gel electrophoresis of dissociated globin chains (Naitana et al, 1990; Masala et al, 1991). Southern blot 
analysis was accomplished on DNA samples obtained from six mouflons selected according to $\mathrm{Hb}$ phenotype ( $3 \mathrm{Hb} \mathrm{B}, 2 \mathrm{Hb} \mathrm{BM}$, and $1 \mathrm{Hb} \mathrm{M}$ ) and, as a comparison, from six sheep (2 $\mathrm{Hb} \mathrm{A}, 2 \mathrm{Hb} \mathrm{AB}$, and $2 \mathrm{Hb} \mathrm{B}$ ). DNA samples were digested with Hind III, Bam HI, and Eco RI and probed with plasmid pG16Ec3Bm2 (containing the $5^{\prime}$ of the goat $\varepsilon^{\mathrm{IV}}$-globin gene) and plasmid pG $\gamma 5^{\prime}$ (containing the $5^{\prime}$ of the goat $\beta^{\mathrm{F}}$-globin gene). According to the hybridization conditions reported by Rando et al (1989), these plasmids (a kind gift from JB Lingrel) strongly cross-hybridize with the paralogous genes.

\section{RESULTS AND DISCUSSION}

Southern blot analysis of mouflon and domestic sheep genomic DNAs digested with Hind III, Bam HI, and Eco RI and hybridized with $\varepsilon^{\mathrm{IV}}$ and $\beta^{\mathrm{F}}$ probes demonstrates that mouflons with $\mathrm{Hb} \mathrm{B}, \mathrm{Hb} \mathrm{BM}$, and $\mathrm{Hb} \mathrm{M}$ show the same electrophoretic patterns as domestic sheep with $\mathrm{Hb} \mathrm{A}, \mathrm{Hb} \mathrm{AB}$, and $\mathrm{Hb} \mathrm{B}$, respectively. As an example, figure 1 shows digestion of mouflon and domestic sheep genomic DNA with Bam $\mathrm{HI}$ and hybridization with the $\varepsilon^{\mathrm{IV}}$ gene. It can be seen that restriction patterns of mouflons with $\mathrm{Hb} \mathrm{B}$ and domestic sheep with $\mathrm{Hb} \mathrm{A}$ (homozygotes for the triplicated haplotype) are characterized by fragments of $9.0,5.5$, and $6.6 \mathrm{~kb}$ containing the $\varepsilon$ pair genes of the juvenile, adult, and fetal sets, respectively (Rando et al, 1989). On the other hand, restriction patterns of mouflons with $\mathrm{Hb} \mathrm{M}$ and domestic sheep with $\mathrm{Hb}$ B (homozygotes for the duplicated haplotype) are characterized by fragments of 5.7 and $6.6 \mathrm{~kb}$ that previous reports show contain the $\varepsilon$ pair genes of the adult and fetal sets, respectively (Garner and Lingrel, 1988; Rando et al, 1989). Figure 2 summarizes results obtained with the three endonucleases and the two probes. Thus the Sardinian mouflon shows two haplotypes at the $\beta$-globin gene

\section{Bam HI}

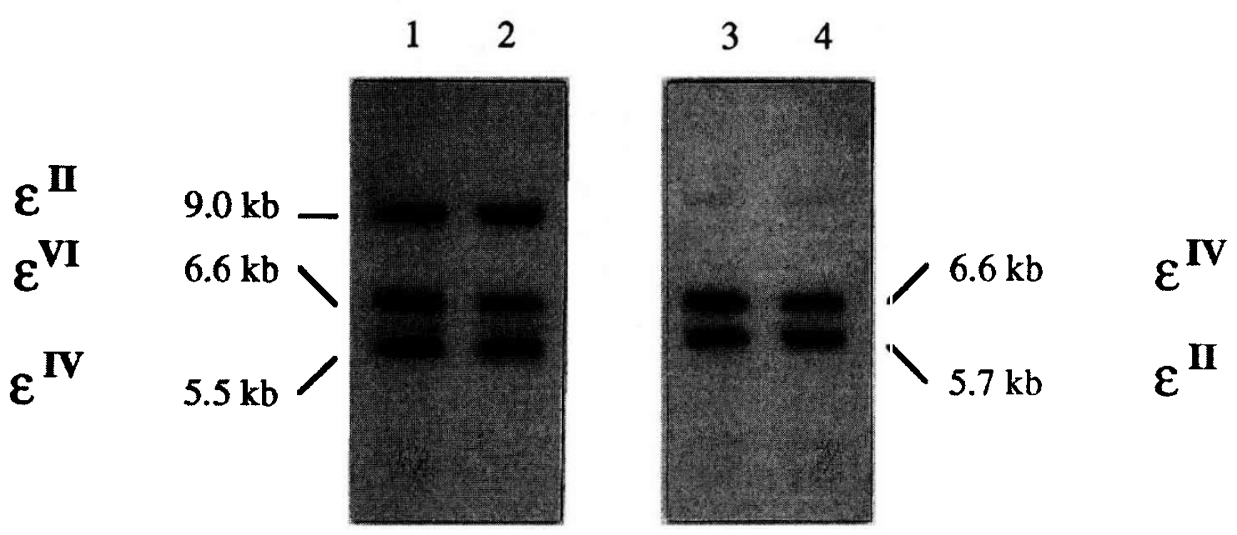

Fig 1. Autoradiograms of mouflon and sheep DNAs digested with Bam HI and probed with the goat $\varepsilon^{\mathrm{IV}}$ gene. Gene nomenclature is according to Garner and Lingrel (1988, 1989). 1: Mouflon Hb B; 2: sheep Hb A; 3: Mouflon Hb M; 4: sheep Hb B. 
Hb B Mouflon - Hb A Sheep

Bam HI

Eco RI

Hind III

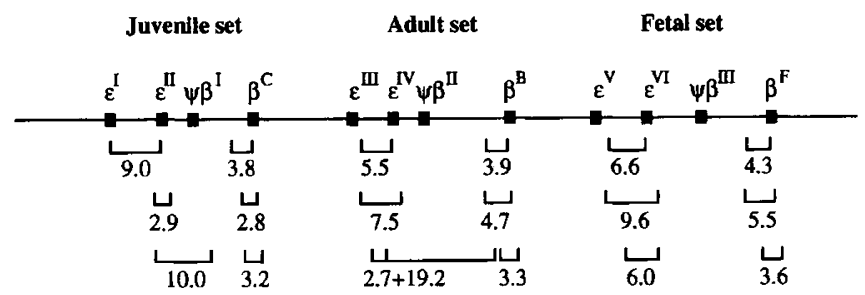

$\stackrel{10 \mathbf{~ k b}}{\longmapsto}$

Hb M Mouflon - Hb B Sheep

Bam HI

Eco RI

Hind III

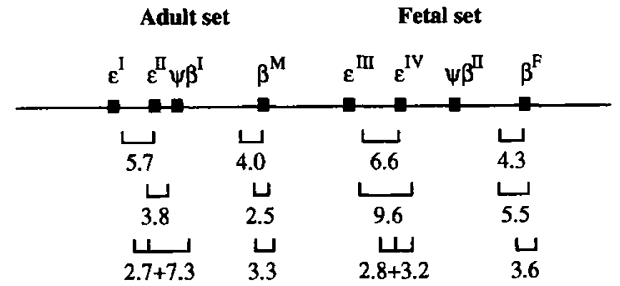

Fig 2. Restriction fragments obtained by hybridizing the goat $\varepsilon^{\mathrm{IV}}$ and $\beta^{\mathrm{F}}$ probes with DNA samples extracted from mouflons homozygous for $\mathrm{Hb} \mathrm{B}$ and $\mathrm{Hb} \mathrm{M}$ and digested with three endonucleases. Fragments of identical length are observed with DNA samples extracted from sheep homozygous for $\mathrm{Hb} \mathrm{A}$ and $\mathrm{Hb} \mathrm{B}$, respectively. Lengths of fragments are given in kilobases. Locations of restriction sites are according to Townes et al (1984), Di Gregorio et al (1987), Garner and Lingrel (1988, 1989), and Rando et al (1989).

cluster, a triplicated one bearing the adult $H B B^{B}$ allele corresponding to the sheep. A haplotype, and a duplicated one bearing the adult $H B B^{M}$ allele corresponding to the sheep B haplotype.

According to the results presented in this paper, the two haplotypes differ not only by the presence/absence of the juvenile set but also by many other mutations evidenced by different restriction endonucleases (see fig 2). The absence of intermediate haplotypes in both sheep (Di Gregorio et al, 1987; Rando et al, 1989) and mouflon confirms the hypothesis that the two haplotypes evolved separately (Boyer et al, 1966) and, at the same time, demonstrates that they were present in ancestor common to both species. According to data presented by Naitana et al (1990), the frequency of the $H B B^{B}$ allele (triplicated switching cluster) is much higher in Sardinian mouflons (0.94) than in domestic sheep and, in particular, in the Sarda breed sheep which is almost monomorphic for the $H B B^{B}$ allele (duplicated non-switching cluster) (Manca et al, 1993) and lives in the same environment. Therefore, it remains to be established whether the marked differences in the frequencies of 'switching' and 'non-switching' chromosomes between Sardinian mouflon and sheep are the result of genetic drift, natural selection or domestication. Masala et al (1991) put forward the possibility of an advantage in synthesizing $\mathrm{Hb} \mathrm{C}$ in a wild-type niche in the case of mouflon. Evans and Turner (1965) evidenced a certain reproductive advantage of the duplicated cluster in sheep. If we consider that the domestic sheep has been the object of selective pressure for milk, wool, and meat production, it could be that man, through domestication and artificial 
selection, is responsible for the high frequency of the duplicated cluster in domestic sheep.

\section{ACKNOWLEDGMENT}

This research was supported by the National Research Council of Italy, Special Project Raisa, Sub-project No 3; Paper No 132578.

\section{REFERENCES}

Boyer SH, Hathaway P, Pascasio F, Orton C, Bardley J, Naughton MA (1966) Hemoglobins in sheep: multiple differences in amino acid sequences of three $\beta$-chains and possible origins. Science 153, 1539-1543

Boyer SH, Crosby EF, Noyes AN, Kaneko JJ, Keeton K, Zinkl J (1968) Hemoglobin switching in non-anemic sheep. Johns Hopkins Med $J$ 123, 92-94

Bunch TD, Foote WC, Spillett JJ (1976) Translocations of acrocentric chromosomes and their implications in the evolution of sheep (Ovis). Cytogenet Cell Genet 17, 122-136

Bunch TD, Nadler CF (1980) Giemsa-band patterns of the tahr and chromosomal evolution of the tribe Caprini. J Hered 71, 110-116

Bunch TD, Nguyen TC (1982) Blood group comparisons between European mouflon sheep and North American desert bighorn sheep. J Hered 73, 112-114

Di Gregorio P, Rando A, Masina P (1987) Differences in the DNA restriction patterns between sheep with $\mathrm{Hb}$ A and $\mathrm{Hb}$ B. Anim Genet 18, 241-247

Evans JV, Turner HN (1965) Haemoglobin type and reproductive performance in Australian merino sheep. Nature 207, 1396-1397

Garner KJ, Lingrel JB (1988) Structural organization of the $\beta$-globin locus of B-haplotype sheep. Mol Biol Evol 5, 134-140

Garner KJ, Lingrel JB (1989) A comparison of the $\beta^{\mathrm{A}}$ - and $\beta^{\mathrm{B}}$-globin gene cluster of sheep. J Mol Evol 28, 175-184

Huisman THJ, Adams HR, Dimmock MO, Edwards WE, Wilson JB (1967) The structure of goat hemoglobins. $J$ Biol Chem 242, 2534-2541

Huisman THJ, Lewis JP, Blunt MH, Adams HR, Miller A, Dozy AM, Boyd EM (1969) Hemoglobin $\mathrm{C}$ in newborn sheep and goats: a possible explanation for its function and biosynthesis. Pediatr Res 3, 189-198

Manca L, Di Luccia A, Pieragostini E, Naitana S, Masala B (1993) Haemoglobin I: a new $\beta$-globin chain variant found in sheep of Italian breeds. Anim Genet 24, 203-204

Manwell C, Baker CMA (1976) Protein polymorphisms in domesticated species: evidence for hybrid origin? In: Population Genetics and Ecology (S Karlin, E Nevo, eds), Academic Press, London, 105-139

Masala B, Manca L, Cocco E, Ledda S, Naitana S (1991) Kinetics of the ontogenic and reversible hemoglobin switching in the mouflon (Ovis musimon) and sheep $\times$ mouflon hybrid. Comp Biochem Physiol 100A, 675-680

Naitana S, Ledda S, Manca L, Cocco E, Masala B (1990) Haemoglobin phenotypes of the wild European mouflon sheep living on the island of Sardinia. Anim Genet 21, 67-75

Poplin F (1979) Origine du mouflon de Corse dans une nouvelle perspective paléontologique, par marronnage. Ann Génét Sél Anim 11, 133-143

Rando A, Di Gregorio P, Masina P (1989) Differences in the number of embryonic and pseudo- $\beta$-globin genes between $\mathrm{HbA}$ and $\mathrm{HbB}$ sheep. Biochem Genet 27, 91-98 
Ryder ML (1984) Sheep. In: Evolution of Domesticated Animals (IL Mason, ed), Longman, London, 63-85

Townes TM, Fitzgerald MC, Lingrel JB (1984) Triplication of a four-gene set during evolution of the goat $\beta$-globin locus produced three genes now expressed differentially during development. Proc Natl Acad Sci USA 81, 6589-6593

Vigne JD (1983) Les mammiferes post-glaciaires de Corse. Étude archéozoologique. Gallia Préhistoire, XXVI supplément, Éditions du CNRS, Paris 